anales de psicología, 2018, vol. 34, nº 1 (january), 63-67 http://dx.doi.org/10.6018/analesps.34.1.262891
(C) Copyright 2018: Editum. Servicio de Publicaciones de la Universidad de Murcia. Murcia (Spain) ISSN print edition: 0212-9728. ISSN web edition (http://revistas.um.es/analesps): 1695-2294

\title{
An examination of the relationship between Emotional Intelligence, Positive Affect and Character Strengths and Virtues
}

\author{
Agnès Ros-Morente*, Carles Alsinet Mora, Cristina Torrelles Nadal, Ana Blasco-Belled, and Norma Jordana Berenguer
}

University of Lleida (Spain).

Título: Un examen de la relación entre Inteligencia Emocional, Afecto Positivo y Fortalezas y Virtudes de Carácter

Resumen: El objetivo del presente estudio fue el de analizar la relación entre la Inteligencia Emocional, el Afecto Positivo y las fortalezas y virtudes descritas en el VIA. Se exploró si la Inteligencia Emocional predecía los niveles de los participantes en las virtudes, además de si el Afecto Positivo constituía un posible mediador. Para ello se utilizaron distintas medidas: 419 estudiantes completaron el Trait Meta-Mood Scale para la Inteligencia Emocional (TMMS, Fernández-Berrocal, Extremera \& Ramos, 2004). Las fortalezas y virtudes fueron evaluadas con el Values in Action Inventory of Strengths (VIA-IS; Peterson, Park, \& Seligman, 2005), y el Afecto Positivo fue evaluado con el Positive (PA) and Negative Affect (NA) Schedule (PANAS; Sandín et al., 1999). Nuestros resultados mostraron una correlación positiva y significativa entre todas las fortalezas y virtudes del VIA con las escalas del TMMS Claridad Emocional y Reparación Emocional. Atención Emocional obtuvo correlaciones significativas para todas las virtudes exceptuando Templanza. Análisis posteriores demostraron que las escalas del TMMS predecían las virtudes del VIA, al mismo tiempo que el Afecto Positivo mostraba un posible rol mediador en la predicción de Templanza y Humanidad. Estos resultados respaldan la relación existente entre Inteligencia Emocional y carácter, así como la importancia del Afecto Positivo en dicha relación.

Palabras clave: Inteligencia Emocional; Afecto Positivo; Fortalezas; Virtudes.

\section{Introduction}

It can be asserted that from a traditional standpoint, psychology has been mainly focusing in those negative aspects of human behaviour, concentrating in individuals' suffering, personal distressors and psychological disorders (Salanova, \& López-Zafra, 2014). This traditional paradigm, although still very present and necessary in the literature, has been partially offset by the emergence of an empirical research trend which envisages psychology from a positive outlook, which is considered as a complementary and needed new approach (Snyder \& Lopez, 2002).

Based on this premise, Peterson and Seligman (2004) proposed a classification of character strengths and virtues. Character strengths are positive traits that are reflected at a cognitive, emotional and behavioural level (Park, Peterson, \& Seligman, 2004). It is important to note, however, that although they bear certain similarities to personality traits, character strengths are considered to be different due to the moral and cultural value placed on them (Peterson \& Seligman, 2004). Character strengths are grouped in a total of six virtue categories, which constitute the core characteristics of

* Correspondence address [Dirección para correspondencia]

Agnès Ros-Morente. Faculty of Education, Psychology and Social Work, University of Lleida. Department of Pedagogy and Psychology. Av. de l'Estudi General, 4. 25001 Lleida (Spain).

E-mail: a.rosmorente@pip.udl.cat
Abstract: The present study had the objective of analysing the relationship between Emotional Intelligence, Positive Affect, VIA's virtues and character strengths. Additionally, it was explored if Emotional Intelligence predicted the virtue's levels of the participants, and if Positive Affect constituted a possible mediator. To that end, different measures were used: 419 undergraduate students completed the Spanish version of the Trait MetaMood Scale for emotional intelligence (TMMS, Fernández-Berrocal, Extremera \& Ramos, 2004). Character strenghts and virtues were assessed with the Values in Action Inventory of Strengths (VIA-IS; Peterson, Park, \& Seligman, 2005), and Positive Affect (PA) was measured with the Spanish version of the Positive and Negative Affect (NA) Schedule (PANAS; Sandín et al., 1999). Our results showed a significant positive correlation between all the VIA strengths and virtues with TMMS scales Emotional Clarity and Emotion Repair. Emotional Attention showed significant correlations for all the virtues except Temperance. Further analyses demonstrated that TMMS scales predicted VIA virtues, and Positive Affect appeared as a possible mediator in the prediction of Temperance and $\mathrm{Hu}$ manity virtues. These results support the relationship between Emotional Intelligence and strength of character, as well as the importance of Positive Affect in this relationship.

Keywords: Emotional Intelligence; Positive Affect; Character Strenghts; Virtues.

character: wisdom, courage, humanity, justice, temperance, and transcendence. Each virtue comprises a number of strengths, up to a total of 24 strengths, such as love or kindness in the virtue of humanity, while the virtue of transcendence includes strengths such as hope or humor (MartínezMartí \& Ruch, 2014).

Evidence shows that some virtues come more naturally to some people than others, but there is the general agreement that strengths and virtues must be practiced in order to become embedded as a natural response (Devettere, 2002). In other words, virtues are proactive by nature, which means that they require active development, practice and habituation (Arjoon, 2008). Although very few studies have specifically studied the relationship between emotional intelligence and virtues and/or character strenghts, there is an acknowledged role of emotions in the individuals' life and well-being, and also in the necessity of benefiting of positive moods (for example, Lyubomirsky et al., 2005). In this sense, it is suggested that emotional intelligence, with particular emphasis on emotion regulation and emotion repair, plays an important part in the development and maintenance of virtues and its character strenghts (Mirowska, 2011). These results offer insights into how individual character strengths are related to emotional intelligence and especially to emotion regulation as well as emotion repair.

Differently, positive emotions in this field have been more explored, showing that positive emotions are related to several beneficial outcomes. Fredrickson (2001), for instance, 
developed a broaden-and-build theory which predicts that positive states enhance self-development, exploration and prosocial behaviours. According to his results, positive emotions also affect mindsets and broaden the range of cognitions and behavioural repertoires an individual engages in (Fredrickson \& Losada, 2005). Additionally, it has been proven that positive emotional states convey certain information to the individual, including feedback regarding their overall state in life and progress towards goals (Lyubomirsky et al., 2005).

In this direction, research so far has shown contradicting results, although several studies show that the endorsement of character strengths, such as hope, zest or love, is significantly related to a higher degree of well-being and Positive Affect (PA) (e.g., Buschor et al., 2013; Martínez-Martí \& Ruch, 2014). At the same time, some authors have found that hope, zest, love, social intelligence, perseverance, and those strenghts related to the use and acquisition of knowledge seem to be the most related character strengths to PA while other authors find that all strengths result significantly and directly related to PA (Azañedo, 2014; MartínezMartí \& Ruch, 2014). Contrary to that, modesty, appreciation of beauty and religiousness seem to be the least associated with PA (Martínez-Martí \& Ruch, 2014).

Thus, given the current state of knowledge and the limited number of studies in the field, in the present work we aimed to study the association between Emotional Intelligence, Positive Affect and VIA's virtues and character strengths. Also, we had the objective of exploring if Emotional Intelligence, measured with the scales of Emotional Attention, Emotional Clarity and Emotional Repair, predicted the virtue's levels of the subjects. Finally, the mediating role of PA in the aforementioned relationship was also studied.

\section{Method}

\section{Participants}

The sample of the study was composed by 419 undergraduate students (84 male and 335 female) of the University of Lleida. Stubjects were recruited when enrolling for a course in the faculty. Participation was completely voluntary and anonymous. Each one of the students signed an informed consent beforehand.

Average age of the total group was 20.17 (SD = 4.22). All of the participants were undergoing programmes of Psychology (23.2\%), Social Work (7.6\%), Social Education (21.5\%), Early childhood Education (11.2\%), Elementary Education $(23.2 \%)$, double degrees $(9.3 \%)$, and other degrees $(4.1 \%)$ at the moment of the study.

\section{Instruments}

Trait Meta-Mood Scale (TMMS-24; Salovey, Mayer, Goldman, Turvey, \& Palfai, 1995). In order to evaluate the way subjects regulated emotion, the Spanish version of TMMS was used. This test enabled assessing perceived emotional intelligence, that is, the meta- knowledge or awareness which people have about their own emotional abilities on a 5-point scale. This scale taps three interpersonal factors with 8 items each: Emotional Attention, Emotional Clarity and Emotional Repair.

The Spanish version of this instrument, carried out by Fernández-Berrocal, Extremera \& Ramos (2004), showed an alfa of Cronbach for each component of 0.86 for Attention, 0.90 for Clarity and 0.86 for Emotional repair.

Positive (PA) and Negative Affect (NA) Schedule (PANAS; Watson, D., 1988). We sought to explore ten affect descriptors with positive mood scales. Participants were asked to respond to this 20 -item test using 5 -point scale that ranges from very slightly or not at all (1) to extremely (5). The Spanish version used in the study was carried out by Sandín, Chorot, Lostao, Joiner, Santed \& Valiente (1999). Internal consistency of the instrument was high, resulting in an Alpha of Cronbach ranging from 0.87 to 0.91 for each scale.

The Values in Action Inventory of Strengths (VLA-IS; Peterson, Park, \& Seligman, 2005). Students completed the survey consistent of 240 questions on a 6-point scale, which assesses 24 strenghts of character, grouped in six universal core factors (virtues): wisdom, courage, humanity, justice, temperance and transcendence. Subjects completed the Spanish version of VIA-IS, which was carried out by Azañedoa, FernándezAbascal, \& Barraca (2014).

\section{Procedure}

All those participants who voluntarily participated in the study filled out the test the aforementioned tests the first day of their classes. To that end, as mentioned before, they were vastly informed about the procedure and they signed an informed consent the day of their enrolament in one of the courses of the faculty. Only those students who completed the whole protocol were accepted in the study.

\section{Statistical Analysis}

The analysis of results the follwoing steps were performed:

a) Descriptive statistics of each variable of the study were obtained.

b) Pearson correlations were executed among all the variables in order to explore the relationship between all the variables of the study.

c) Hierarchical multiple regression analysis were completed in order to test the predictive power of emotional variables and PA for each one of the virtues. The first step of the regression included solely the emotional variables, while the second step added PA in order to test its mediational role. 


\section{Results}

Table 1 shows the means, standard deviations and the range of 24 VIA strengths and 6 VIA virtues, the 3 scales of TMMS-24 and the PA scale of PANAS for the total sample.

Table 1. Descriptive statistics of the study variables.

\begin{tabular}{|c|c|c|c|}
\hline Measures & Mean & $S D$ & Range \\
\hline VIA.Wisdom & 18.86 & 2.35 & 12.2 \\
\hline Creativity & 3.73 & 0.66 & 3.30 \\
\hline Curiosity & 3.87 & 0.53 & 2.80 \\
\hline Judgement & 3.94 & 0.56 & 3.30 \\
\hline Love of learning & 3.57 & 0.63 & 3.10 \\
\hline Perspective & 3.74 & 0.64 & 2.90 \\
\hline VIA. Courage & 15.64 & 1.89 & 11.8 \\
\hline Bravery & 3.85 & 0.58 & 3.10 \\
\hline Perseverance & 3.88 & 0.64 & 3.40 \\
\hline Honesty & 4.15 & 0.49 & 3.20 \\
\hline Zest & 3.74 & 0.57 & 3.10 \\
\hline VIA. Humanity & 12.38 & 1.36 & 9.5 \\
\hline Love & 4.12 & 0.55 & 3.50 \\
\hline Kindness & 4.25 & 0.52 & 3.20 \\
\hline Social Intelligence & 3.98 & 0.51 & 3.20 \\
\hline VIA. Justice & 12.29 & 1.44 & 10.0 \\
\hline Teamwork & 4.06 & 0.53 & 3.40 \\
\hline Fairness & 4.15 & 0.54 & 3.50 \\
\hline Leadership & 4.06 & 0.51 & 3.10 \\
\hline VIA. Temperance & 14.31 & 1.94 & 12.1 \\
\hline Forgiveness & 3.66 & 0.63 & 3.60 \\
\hline Humility & 3.62 & 0.58 & 3.20 \\
\hline Prudence & 3.49 & 0.63 & 3.30 \\
\hline Self-regulation & 3.52 & 0.60 & 3.80 \\
\hline VIA.Transcendence & 18.70 & 2.27 & 14.5 \\
\hline Appreciation of beauty and Excellence & 3.75 & 0.64 & 3.30 \\
\hline Gratitude & 4.01 & 0.53 & 3.40 \\
\hline Hope & 3.95 & 0.58 & 3.20 \\
\hline Humor & 4.04 & 0.58 & 3.30 \\
\hline Spirituality & 2.94 & 0.76 & 3.90 \\
\hline \multicolumn{4}{|l|}{ TMMS-24. } \\
\hline Emotional Attention & 29.93 & 5.57 & 25 \\
\hline Emotional Clarity & 29.64 & 5.46 & 24 \\
\hline Emotional Repair & 30.02 & 5.53 & 26 \\
\hline \multicolumn{4}{|l|}{ PANAS. } \\
\hline Positive Affect (standarized score) & 0.00 & 1.00 & 5.35 \\
\hline
\end{tabular}

Note: VIA survey (long form); TMMS: Trait meta-mood scale for emotional intelligence; PANAS: Positive and negative affect schedule (Positive Affect scale).

Pearson correlations among measures are shown in Table 2. As expected, our results yield a significant positive correlation between all the VIA strengths and virtues and TMMS24 scales Emotional Clarity and Emotion Repair. Differently, Emotional Attention showed more selective correlations, specifically, positive and significant correlations emerged for all the virtues except Temperance. Character strenghts also showed some significant associations, being Humanity the virtue with more significative character strenghts (see Table 2).
Table 2. Correlations among measures.

\begin{tabular}{|c|c|c|c|c|}
\hline & $\begin{array}{l}\text { Emotional } \\
\text { Attention }\end{array}$ & $\begin{array}{c}\text { Emotional } \\
\text { Clarity }\end{array}$ & $\begin{array}{c}\text { Emotional } \\
\text { Repair }\end{array}$ & $\begin{array}{c}\text { Positive } \\
\text { Affect }\end{array}$ \\
\hline Wisdom & $.140 * * *$ & $.353^{* * *}$ & $.379 * * *$ & $.365^{* * *}$ \\
\hline Creativity & $.147 * * *$ & $.246 * * *$ & $.322 * * *$ & $.262^{* * *}$ \\
\hline Curiosity & .075 & $.312 * * *$ & $.352 * * *$ & $.332 * * *$ \\
\hline Judgement & $.149 * * *$ & $.320 * * *$ & $.251 * * *$ & $.289 * * *$ \\
\hline Love of learning & .078 & $.230 * * *$ & $.296 * * *$ & $.294 * * *$ \\
\hline Perspective & $.108^{*}$ & $.329 * * *$ & $.303^{* * *}$ & $.313^{* * *}$ \\
\hline Courage & $.118^{*}$ & $.366^{* * *}$ & $.330 * * *$ & $.396^{* * *}$ \\
\hline Bravery & .090 & $.309 * * *$ & $.282^{* * *}$ & $.295^{* * *}$ \\
\hline Perseverance & .068 & $.285^{* * *}$ & $.236 * * *$ & $.347 * * *$ \\
\hline Honesty & .065 & $.362 * * *$ & $.131 * * *$ & $.267 * * *$ \\
\hline Zest & $.168^{* * *}$ & $.266 * * *$ & $.427 * * *$ & $.400 * * *$ \\
\hline Humanity & $.154 * * *$ & $.350 * * *$ & $.254 * * *$ & $.333 * * *$ \\
\hline Love & $.168^{* * *}$ & $.290 * * *$ & $.215^{* * *}$ & $.290 * * *$ \\
\hline Kindness & $.155^{* * *}$ & $.204 * * *$ & $.199 * * *$ & $.252 * * *$ \\
\hline Social Intelligence & $.122^{*}$ & $.410^{* * *}$ & $.241 * * *$ & $.320 * * *$ \\
\hline Justice & $.138 *$ & $.258 * * *$ & $.292 * * *$ & $.322 * * *$ \\
\hline Teamwork & $.103^{*}$ & $.241 * * *$ & $.262 * * *$ & $.307 * * *$ \\
\hline \multicolumn{5}{|l|}{ Fairness } \\
\hline Leadership & $.129 * * *$ & $.249 * * *$ & $.288^{* * *}$ & $.322 * * *$ \\
\hline Temperance & .090 & $.194 * * *$ & $.195^{* * *}$ & $.309 * * *$ \\
\hline Forgiveness & $.098^{*}$ & $.118^{*}$ & $.323^{* * *}$ & $.254 * * *$ \\
\hline Humility & .078 & $.154 * * *$ & .043 & $.220 * * *$ \\
\hline Prudence & $.130 * * *$ & $.185^{* * *}$ & .072 & $.200 * * *$ \\
\hline Self-Regulation & -.026 & $.154 * * *$ & $.168^{* * *}$ & $.302^{* * *}$ \\
\hline Transcendence & $.205^{* * *}$ & $.292 * * *$ & $.380^{* * *}$ & $.371 * * *$ \\
\hline Appreciation of beauty & $.282 * * *$ & $.238^{* * *}$ & $.236 * * *$ & $.283^{* * *}$ \\
\hline Excellence & $.142 * * *$ & $.214^{* * *}$ & $.245^{* * *}$ & $.247 * * *$ \\
\hline Gratitude & $.190^{* * *}$ & $.232 * * *$ & $.202 * * *$ & $.293^{* * *}$ \\
\hline Hope & .072 & $.299 * * *$ & $.441 * * *$ & $.348^{* * *}$ \\
\hline Humor & .024 & $.165^{* * *}$ & $.323^{* * *}$ & $.209 * * *$ \\
\hline Spirituality & $.165^{* * *}$ & $.151 * * *$ & $.204 * * *$ & $.244 * * *$ \\
\hline \multicolumn{5}{|l|}{$T M M S-24$} \\
\hline Emotional Attention & - & - & - & .091 \\
\hline Emotional Clarity & - & - & - & $.233^{* * *}$ \\
\hline Emotional Repair & - & - & - & $.268^{* * *}$ \\
\hline
\end{tabular}

When further analysing Positive Affect, results showed that all the character strenghts and virtues of VIA correlated significantly, with values ranging from .200 (Prudence) to .400 (Zest). Regarding TMMS-24, Emotional Clarity and Emotional Repair also showed a significant positive correlation, with .233 and .268 values respectively.

Additionally, in order to study the role of PA in the relationship between emotional intelligence and virtues, we carried out a hierarchical regression model for each one of the virtues and we examied the potential mediating contribution that PA may have in the model. The first step of the model introduces TMMS-24 scales as possible predictors and one of the virtues. The second step introduces, in addition to the TMMS-24 scales, the PA scale. Those predictors which change their significance within the model when PA is added, may suggest a mediation effect of the latest variable. 
All the models that were tested showed that TMMS-24 variables contribute to the model when predicting for the virtues, showing high significance and a relevant difference among R-squared when introducing PA. The increase among $\mathrm{R}$-squared indexes of the analysed models ranges from .202 to .258 for Wisdom, from .189 to .266 for Courage, from .161 to .213 for Humanity, from .127 to .177 for Justice, from .074 to .131 for Temperance and from .185 to .248 for Transcendence.

Although the overall total variation of the model was not always high, it is important to note that all the entered varia- bles resulted as highly significant contributors for the model. Moreover, in an attempt to go a step further and so as to explore the mediating role of PA, the changes in significance for all the independent variables were studied in further detail. Results showed that when predicting Temperance and Humanity, Emotional Repair shows a possible mediating effect of PA (see Tables 3 and 4). That is, when introducing PA in the model, Emotion Repair becomes non-significant, while the explained variability of the model increases up to a $21.3 \%$ for Humanity and a $13.1 \%$ for Temperance.

Table 3. Hierarchical multiple regression analysis and mediation for the scales of TMMS-24, Positive Affect scale of PANAS predicting Temperance virtue of VIA.

\begin{tabular}{|c|c|c|c|c|c|c|c|}
\hline & $\mathrm{R}^{2}$ & $F$ & $B$ & SE(B) & $\beta$ & $p$ & \\
\hline Step 1: TMMS-24 variables & .074 & 10.13 & & & & & $<0.001$ \\
\hline Emotional Attention & & & .234 & .178 & .066 & .190 & \\
\hline Emotional Clarity & & & .634 & .191 & .177 & .001 & \\
\hline Emotional Repair & & & .459 & .185 & .129 & .013 & \\
\hline Step 1: TMMS-24 variables and Positive Affect & .131 & 14.33 & & & & & $<0.001$ \\
\hline Emotional Attention & & & .197 & .173 & .056 & .257 & \\
\hline Emotional Clarity & & & .496 & .187 & .138 & .008 & \\
\hline Emotional Repair & & & .267 & .183 & .075 & .145 & \\
\hline Positive Affect & & & 4.913 & .983 & .251 & .000 & \\
\hline
\end{tabular}

Note: VIA survey (long form); TMMS-24: Trait meta-mood scale for emotional intelligence; PANAS: Positive and negative affect schedule (Positive Affect scale).

Table 4. Hierarchical multiple regression analysis and mediation for the scales of TMMS-24, Positive Affect scale of PANAS predicting Humanity virtue of VIA.

\begin{tabular}{|c|c|c|c|c|c|c|c|}
\hline & $\mathrm{R}^{2}$ & $F$ & $B$ & $S E(B)$ & $\beta$ & $p$ & \\
\hline Step 1: TMMS-24 variables & .161 & 24.43 & & & & & $<0.001$ \\
\hline Emotional Attention & & & .258 & .122 & .106 & .000 & \\
\hline Emotional Clarity & & & .752 & .130 & .293 & .028 & \\
\hline Emotional Repair & & & .368 & .126 & .145 & .004 & \\
\hline Step 1: TMMS-24 variables and Positive Affect & .213 & 25.73 & & & & & $<0.001$ \\
\hline Emotional Attention & & & .243 & .118 & .096 & .041 & \\
\hline Emotional Clarity & & & .657 & .128 & .256 & .000 & \\
\hline Emotional Repair & & & .236 & .125 & .093 & .058 & \\
\hline Positive Affect & & & 3.352 & .670 & .269 & .000 & \\
\hline
\end{tabular}

Note: VIA survey (long form); TMMS-24: Trait meta-mood scale for emotional intelligence; PANAS: Positive and negative affect schedule

(Positive Affect scale).

\section{Discussion and Conclusions}

The present study aimed at analysing the relationship between Emotional Intelligence, Positive Affect and VIA's virtues and character strengths. We also intended to explore if Emotional Intelligence predicted the virtue's levels of the participants, as well as the possible mediating role of Positive Affect.

Despite the scarcity of studies regarding Emotional Intelligence and character, our results are in line with those previous ones showing that character is associated with emotional abilities and Positive Affect, becoming evident that some strengths and virtues consistently seem to yield higher correlations than others (Lyubomirsky et al., 2005; Martínez-Martí \& Ruch, 2014). Specifically, our results showed a significant positive correlation between all the VIA strengths and virtues and TMMS-24 scales Emotional Clarity and Emotion
Repair. However, Emotional Attention showed more selective correlations, emerging positive and significant correlations for all the virtues except Temperance. This finding appeared as consistent with previous literature that exhibited more association with emotion regulation than other emotional skills. This can be explained by the fact that a less functional regulation of the emotions has a greater and a more stable impact in character and affect than other skills, more related to the awareness and identification of the emotion itself.

When exploring if Emotional Intelligence predicted the virtue's levels of the participants and the possible mediating role of Positive Affect, our results showed that all TMMS-24 scales predicted virtue's levels in a discreet but significant way. Additionally, when predicting the virtues of Temperance and Humanity, it appeared a possible mediating role of Positive Affect. In the first hierarchical step of the regres- 
sion, Emotional Repair scale of TMMS-24 was significant, but when introducing Positive Affect in the second step of the regression, this scale ceased its significance. This can be explained because Emotional Repair only leads to high levels of Humanity and Temperance when Positive Affect emerges. That is, an individual exhibits high levels of Humanity and Temperance by means of having a positive affection. This is consistent with previous evidence, which shows that regulating and repairing emotions and, ultimately, being emotionaly efficient, leads to a higher satisfaction, Positive Affect and a healthier mindset, which at the same time, brings individuals to a better psychological adjustment and character features

\section{References}

Arjoon, S. (2008). Reconciling situational social psychology with virtue ethics. International Journal of Management Reviews. 10(3), 221-243. DOI: 10.1111/j.1468-2370.2007.00216.x

Azañedo, C. M., Fernández-Abascal, E. G., \& Barraca. J. (2014). Character strengths in Spain: Validation of the Values in Action Inventory of Strengths VIA-IS) in a Spanish sample. Clínica y Salud, 252, 123-130. DOI: $10.1016 /$ j.clysa.2014.06.002

Buschor, C., Proyer, R. T., \& Ruch, W. (2013). Self-and peer-rated character strengths: How do they relate to satisfaction with life and orientations to happiness?. The Journal of Positive Psychology, 82, 116-127. DOI:10.1080/17439760.2012.758305

Devettere, R. J. (2002). Introduction to virtue ethics: Insights of the ancient Greeks. Washington, D.C.: Georgetown University Press.

Fernández-Berrocal, P., Ramos, N., \& Extremera, N. (2001). Inteligencia emocional, supresión crónica de pensamientos y ajuste psicológico. Boletín de psicología. 70, 79-95.

Fredrickson, B., L. (2001). The role of positive emotions in positive psychology: The broaden-and-build theory of positive emotions. American Psychologist. 56(3), 218- 226. DOI: 10.1037/0003-066X.56.3.218

Fredrickson, B., L., \& Losada, M. F. (2005). Positive Affect and the complex dynamics of human flourishing, American Psychologist. 60(7), 678686. DOI: 10.1037/0003-066X.60.7.678

Lyubomirsky, S. King, L., Diener, E. (2005). The benefits of frequent Positive Affect: does happiness lead to success?, Psychological Bulletin. 131(6), 803. DOI: $10.1037 / 0033-2909.131 .6 .803$

Martínez-Martí, M. L., \& Ruch, W. (2014). Character strengths and wellbeing across the life span: data from a representative sample of Ger-
(Fernández-Berrocal, P., Ramos, N., \& Extremera, N.; 2001; Nolen-Hoeksema, S., \& Aldao, A., 2011).

It is important to note that until now, most studies have focused on samples whose representativeness becomes limited. Studied participants are normally individuals from convenience samples that typically result in biased samples. Also, there is evidence showing that there may be differences among the relationship existing among character and affect and well-being (Martí \& Ruch, 2014). Our results were obtained form a sample of undergraduate students, which show a certain amount of homogeneity regarding their characteristics and age. Therefore, we believe that future studies shoud be carried out with samples which amend this pitfalls.

man-speaking adults living in Switzerland, Frontiers in Psychology. 5, 1253. DOI: 10.3389 /fpsyg.2014.01253

Mirowska, A. (2011). Character at Work: A Virtues Approach to Creativity and Emotion Regulation (PhD Thesis). McMaster University, Ontario.

Nolen-Hoeksema, S., \& Aldao, A. (2011). Gender and age differences in emotion regulation strategies and their relationship to depressive symptoms, Personality and Individual Differences. 51(6), 704-708. DOI: 10.1016/j.paid.2011.06.012

Park. N., Peterson, C., \& Seligman, M. E. P. (2004). Strengths of character and well-being. Journal of Social and Clinical Psychology. 2, 603-619, DOI: 10.1521/jscp.23.5.603.50748.

Ruch. W., Martínez-Martí, M. L., Proyer, R. T., \& Harzer, C. (2014). The character strengths rating form (CSRF): development and initial assessment of a 24-Item rating scale to assess character strengths, Personality and Individual Differences. 68, 53-58. DOI: 10.1016/j.paid.2014.03.042

Salanova. M., \& López-Zafra, E. (2011). Introducción: Psicología social y psicología positiva, Revista de Psicología Social. 263, 339-343. DOI: 10.1174/021347411797361248

Snyder, C. R., Lopez, S. J. (Eds) (2002). The future of positive psychology: A declaration of independence. Handbook of positive psychology. New York, Oxford University Press.

Watson, D., Clark, L. A., \& Tellegan, A. (1988). Development and validation of brief measures of positive and negative affect: The PANAS scales. Journal of Personality and Social Psychology, 54(6), 1063-1070. DOI: 10.1037/0022-3514.54.6.1063

(Article received: 07-07-2016; revised: 28-11-2016; accepted: 12-12-2016) 